\title{
Heart-hand syndrome, Slovenian type
}

INSERM

\section{Source}

INSERM. (1999). Orphanet: an online rare disease and orphan drug data base. Hearthand syndrome, Slovenian type. ORPHA:168796

Heart-hand syndrome of Slovenian type is a rare autosomal dominant form of hearthand syndrome (see this term), first described in members of a Slovenian family, that is characterized by adult onset, progressive cardiac conduction disease, tachyarrhythmias that can lead to sudden death, dilated cardiomyopathy and brachydactyly, with the hands less severely affected than the feet. Muscle weakness and/or myopathic electromyographic findings have been observed in some cases. 